\title{
Phenology, litterfall, growth, and root biomass in a tidal floodplain forest in the Amazon estuary
}

\author{
JOSÉ H. CATTANIO ${ }^{1,3}$, ANTHONY B. ANDERSON ${ }^{1}$, \\ JOHN S. ROMBOLD ${ }^{1}$ and DANIEL C. NEPSTAD ${ }^{2}$
}

(received: February 25, 2003; accepted: July 29, 2004)

\begin{abstract}
Phenology, litterfall, growth, and root biomass in a tidal floodplain forest in the Amazon estuary). The dynamics of forests subject to inundation appears to be strongly influenced by the frequency and intensity of natural disturbances such as flooding. In a late successional tidal floodplain forest near the Amazon port of Belém, Brazil, we tested this prediction by measuring seasonal patterns of phenology and litterfall in relation to two key variables: rainfall and tide levels. In addition, we estimated the root biomass and the annual growth of the forest community by measuring stem increments over time. Our results showed high correlations between phenological events (flowering and fruiting) and rainfall and tide levels, while correlations between litterfall and these variations were generally weaker. Contrary to our prediction, root biomass to $1 \mathrm{~m}$ depth showed no significant differences along the topographic gradient, and the root biomass at all topographic levels was low to intermediate compared with other neotropical forests. Both litterfall and total stem increment were high compared to other tropical forest, indicating the high productivity of this ecosystem.
\end{abstract}

Key words - Amazon, floodplain forest, litterfall, Phenology, productivity

RESUMO - (Fenologia, queda de serrapilheira, biomassa de raízes e crescimento em uma floresta de várzea no estuário Amazônico). A dinâmica de floresta sujeita à inundação parece ser fortemente influenciada pela freqüência e intensidade de distúrbios naturais como a inundação. Em uma antiga floresta sucessional de várzea próxima ao porto de Belém, Brasil, testouse esta hipótese pela medição sazonal dos padrões de fenologia, incluindo queda de serrapilheira, em relação a duas variáveis chaves: chuva e nível da maré. Em adição, estimamos o crescimento anual da comunidade florestal pela medição do incremento do diâmetro de troncos ao longo do tempo e desenvolvimento radicular. Encontrou-se alta correlação entre florescimento e frutificação com chuva e nível da maré, porém as correlações entre a queda da serrapilheira e estas variáveis foram geralmente fracas. Ao contrario de nossa hipótese, biomassa de raízes até $1 \mathrm{~m}$ de profundidade não variou significativamente ao longo do gradiente topográfico, e esta foi menor a intermediária em todos os níveis topográficos do que em outras florestas neotropicais. A queda de serrapilheira e o incremento de troncos foram superiores do que em outras florestas tropicais, indicando uma alta produtividade neste ecossistema.

Palavras-chave - Amazônia, Fenologia, floresta de várzea, produtividade, queda de serrapilheira

\section{Introduction}

The floodplain (várzeas) covers around $180,000 \mathrm{~km}^{2}$, about $2.6 \%$ of the 7 million- $\mathrm{km}^{2}$ area of the Amazon basin (Bayley \& Petrere 1989). The floodplain of the Amazon River and its white-water tributaries has long been recognized as among the most suitable sites for agriculture in the Amazon basin, due to its abundant and nutrient-rich sediments (Lima 1956, Meggers 1971, Falesi 1974, Roosevelt 1980). This suitability, however, varies considerably along the course of the Amazon. For example, sediment concentrations as well as $\mathrm{pH}$ decline

1. Universidade Federal Rural da Amazônia, Departamento de Ciências Florestais, Av. Presidente Tancredo Neves, 2501, Bairro Montese, Caixa Postal 917, 66077-530 Belém, PA, Brasil.

2. Woods Hole Research Center, Woods Hole, USA.

3. Corresponding author: cattanio@cpatu.embrapa.br markedly between the Upper Amazon and the estuary (Gibbs 1967, Irion 1983). This decline can be attributed to the low suspension loads of most of the tributaries in the middle and lower sections of the Amazon. Pronounced variations in flood duration also occur between upstream areas and the estuary. As the Amazon widens downstream and tidal influences increase, flooding becomes less pronounced but more frequent. The combination of these factors produces soils that are not only poor in nutrients compared to upriver areas, but excessively humid during most of the year (Sioli \& Kling 1962).

The economic importance of floodplain forests in the Amazon estuary indicates the need for sustained management of this ecosystem. Yet little ecological information has been published on these forests that could serve as a basis for their management. Conditions for agriculture thus appear to be less favorable in the estuarine floodplain, and agricultural production is, in fact, 
chronically low (Lima 1956). The major land use in this ecosystem is forestry rather than agriculture, and most of the local population harvests forest products such as fruits, fibers, timber, game, and fish for their livelihood (Padoch et al. 1985, Anderson 1990).

Despite the economic importance of floodplain forests, little is known concerning the structural or functional aspects of these ecosystems. Compared with upland forests of the Amazon basin, inundated forest types are characterized by reduced biodiversity and pronounced dominance of a few species, many of which are economically important (Lima 1956, Pires \& Koury 1958, Salo et al. 1986, Gentry \& Dodson 1987, Anderson 1990, Kahn \& Mejia 1990, Cattanio et al. 2002). Although considered to be relatively homogenous, floodplain forest in the Amazon estuary undergoes pronounced variation in floristic composition and structure in response to slight changes in topography (Pires \& Koury 1958, Cattanio et al. 2002).

Likewise, the dynamics of forests subjected to inundation appears to be strongly influenced by the frequency and intensity of natural disturbances such as flooding (Frangi \& Lugo 1985). In addition, these forests appear to be especially responsible to anthropogenic disturbances (Anderson 1990) and a small number of information exists on this important ecosystem. To test these predictions, we selected a late successional tidal floodplain forest, which do not have more anthropogenic disturbances (during 60 years), near the major Amazon port of Belém, Brazil. Here we examined seasonal patterns of phenology and litterfall in relation to two key abiotic factors: rainfall and tide levels. In addition, we quantified the root biomass and annual aboveground productivity of the forest community by measuring thick and fine roots, and the stem increments and litterfall over time.

\section{Materials and methods}

The study site - This study was carried out on Combu island (lat. $48^{\circ} 25^{\prime} 54^{\prime \prime}$ to $48^{\circ} 29^{\prime} 34^{\prime \prime} \mathrm{W}$, long. $01^{\circ} 29^{\prime} 20^{\prime \prime}$ to $01^{\circ} 31^{\prime} 11^{\prime \prime} \mathrm{S}$ ), located $2 \mathrm{~km}$ South of Belém (figure 1). Mean monthly temperatures vary from $26^{\circ} \mathrm{C}$ to $27^{\circ} \mathrm{C}$, and mean annual rainfall is $2,800 \mathrm{~mm}$ (SUDAM 1984). In relation of upland, the island exhibits low topographic relief, ranging from $291-382 \mathrm{~cm}$ above mean sea level (for more detail see Cattanio et al. 2002). Like other islands and adjacent mainland areas in the Amazon estuary, Combu is subjected to both tide-driven and seasonal flooding. Tide-driven floods occur diurnally and attain maximum amplitudes during the equinoxes. Imposed on tidedriven floods are seasonal variations in rainfall, which also contribute to flooding. As a result, water levels are higher during the rainy season (December-May) than during the dry season (June-November). The most intensive floods occur during the March-April equinox, which coincides with

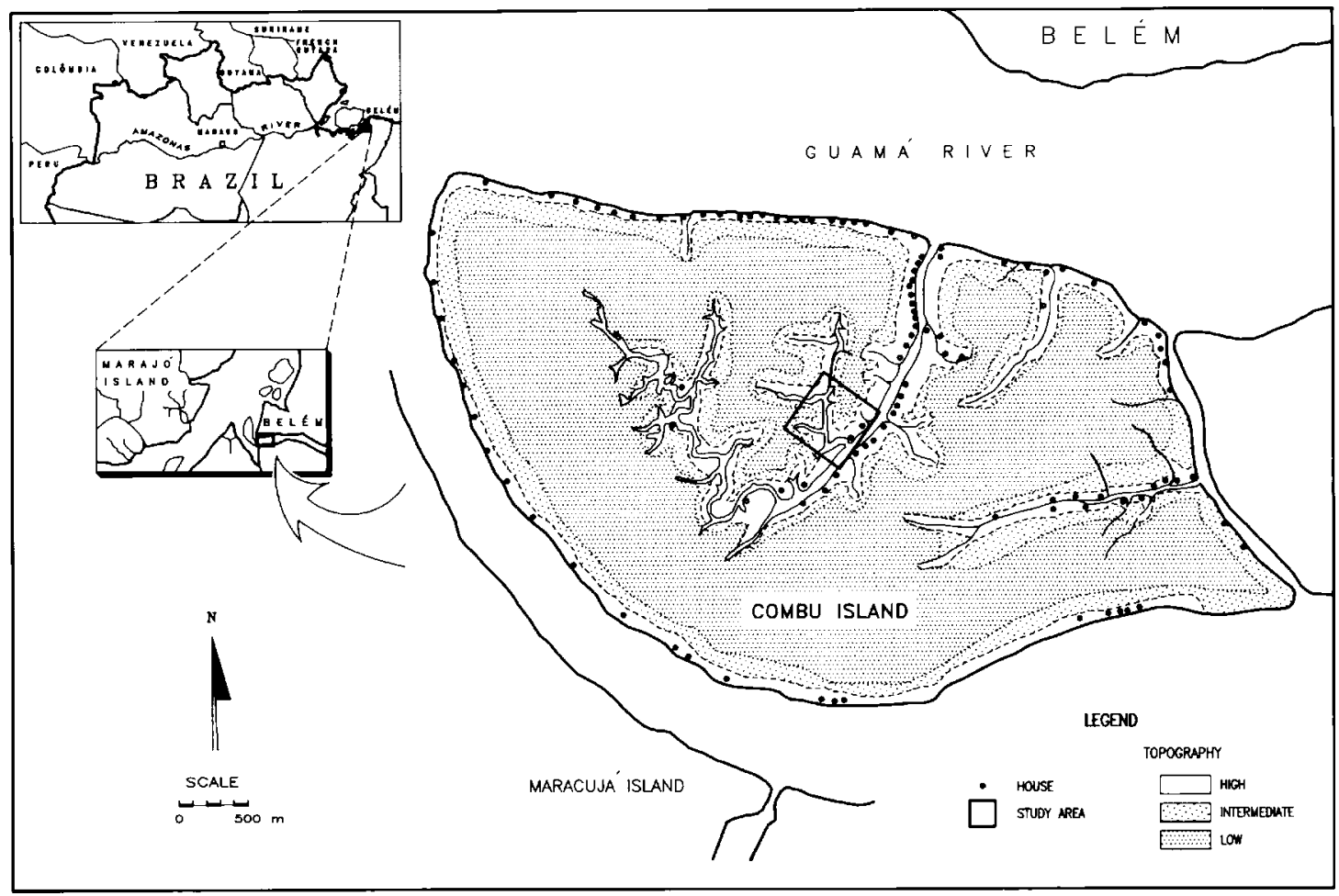

Figure 1. Location of study site in the Amazon estuary and distribution of topographic zones and households on Combu island, Belém, PA, Brazil. 
the high water levels of the rainy season. During these months, the entire floodplain is inundated when the tidedriven floods peak at the full and new moons (Lima 1956).

Flooding exerts a profound influence on the soil and vegetation of Combu island. The predominant soil is a low humic gley (Vieira 1979), characterized by a high percentage of kaolinite clay and a low absence of sand (Falesi 1974). Oscillations in the water table result in alternating soil oxidation and reduction, which produce gleying (Sioli 1951). Due to low infiltration and a general lack of topographic relief, this soil is poorly drained and consequently poor in oxygen (anoxic).

Fieldwork was carried out in late successional floodplain forest that, according to local informants, had suffered little or no disturbance over the past 40 years. Measurements were made within twenty $20 \times 25 \mathrm{~m}$ plots established for vegetational sampling in the central part of the island (for more details see Cattanio et al. 2002). These plots were located on topographically intermediate sites, at a mean altitude of $336 \pm 1.3 \mathrm{~cm}$ (mean \pm standard error) above mean sea level. Abiotic factors - Monthly data on rainfall in Belém for the years 1982-1989 (available data for the tidal level and rainfall) were obtained from the "Superintendência do Desenvolvimento da Amazônia (SUDAM)". Daily data on the tidal levels in Belém for the same period were obtained from the "Companhia Docas do Pará". Measurements of both rainfall and tide levels were made within $3 \mathrm{~km}$ of Combu island. Tide levels were calculated as the mean of all high tides for each month.

Phenology - Data on flowering and fruiting were obtained from a long-term phenological study of 56 tree species conducted on Combu island. As part of that study, a minimum of five individuals of each species was observed at two-week intervals. To determine phenological patterns at the community level, we selected 15 of the most ecologically important species, which together represented ca. $60 \%$ of the importance value of all species with diameter at breast height $(\mathrm{dbh}) \geq 5 \mathrm{~cm}$ found in one hectare of floodplain forest on Combu (see Cattanio et al. 2002). For each species, the proportion of individuals observed in flower at a given date was multiplied by its relative importance value among the group of species selected, the sum of products for all 15 species represented a community flowering index, which varied from zero to hundred. A similar procedure was followed to calculate a community fruiting index.

Litterfall - Litter traps were constructed with $1 \mathrm{~m}^{2}$ nylon mesh $(1.0 \mathrm{~mm})$ mounted in a frame comprised of four PVC tubes, suspended $20 \mathrm{~cm}$ above the soil surface and attached to wooden stakes. Five traps were established in each of six vegetation sampling plots, giving a total of 30 traps. Litter samples were collected monthly from January through December 1989, placed in plastic bags and later manually separated into i) flowers and fruits, ii) leaves, and iii) branches. Each sample was oven-dried at $60{ }^{\circ} \mathrm{C}$ for 72 hours and subsequently weighed.

Root distribution - To measure the root biomass in the topographically high, intermediate, and low floodplain forest communities (for topographical altitudes see Cattanio et al. 2002), we collected samples of thick and fine roots at two periods of the year to represent the extremes of the flooding regime: April-May 1988, which corresponds to the rainy season, when mean water levels are relatively high, and November-December 1988, corresponding to the dry season, when mean water levels are relatively low. The results obtained during the two seasons were subsequently averaged. Root sampling techniques followed methods described by Schuurman \& Goedewaagen (1965). At each topographic position, we dug ten square pits $0.5 \mathrm{~m}$ wide and $1.0 \mathrm{~m}$ depth for collection of root samples. For each $20 \mathrm{~cm}$ depth interval, a soil sample was extracted with a volumetric ring for determination of bulk density (table 1). In addition, for each $10 \mathrm{~cm}$ depth interval, all live and dead thick roots $(>2 \mathrm{~mm}$ in diameter) were separated from the soil, washed, and placed in plastic bags for subsequent laboratory analysis.

In the laboratory, at each topographic position, fine roots

Table 1 . Soil bulk density by depth on topographically high, intermediate, and low sites on Combu island. The number correspond to median (standard error).

\begin{tabular}{lccc}
\hline Depth $(\mathrm{cm})$ & \multicolumn{3}{c}{ Topographic position $\left(\mathrm{g} \mathrm{cm}^{-3}\right)$} \\
\cline { 2 - 4 } & High & Intermediary & \multicolumn{1}{c}{ Low } \\
\hline $00-20$ & $1.42 \pm 0.03$ & $1.25 \pm 0.02$ & $1.10 \pm 0.03$ \\
$20-40$ & $1.36 \pm 0.03$ & $1.44 \pm 0.02$ & $1.12 \pm 0.03$ \\
$40-60$ & $1.47 \pm 0.03$ & $1.51 \pm 0.02$ & $1.21 \pm 0.04$ \\
$60-80$ & $1.49 \pm 0.02$ & $1.53 \pm 0.01$ & $1.25 \pm 0.04$ \\
$80-100$ & $1.47 \pm 0.02$ & $1.40 \pm 0.04$ & $1.13 \pm 0.03$ \\
\hline
\end{tabular}

( $\geq 2 \mathrm{~mm}$ in diameter) were sampled with a $100 \mathrm{~cm}^{2}$ auger in 24 holes to one meter depth. The holes were bored around the perimeter of six thick-root pits previously described. The fine root samples were washed in salt water $\left(50 \mathrm{~g}\right.$ of $\mathrm{NaCl} 10 \mathrm{~L}^{-1}$ of water) and passed repeatedly through a fine-meshed $(0.5 \mathrm{~mm})$ nylon filter to separate fine roots from mineral soil. The separated material was stored in plastic bags containing ethanol (96\%). Each sample of thick roots was oven-dried at $60{ }^{\circ} \mathrm{C}$ and subsequently weighted. Fine root samples were manually sorted from non-root material prior to drying and weighing.

Growth - In July 1987, the diameters of all a live plants with $\mathrm{dbh} \geq 5.0 \mathrm{~cm}$ were measured in each of the twenty $0.05 \mathrm{ha}$ plots (1.0 ha) as part of a study of floodplain forest structure (Cattanio et al. 2002). Eight of the plots were then designated for long-term growth measurements: four as controls and four in which $50 \%$ of the canopy cover was removed by girding. In July 1990, the diameters of all live plants with dbh $\geq 5 \mathrm{~cm}$ were remeasured in these plots. Diameter measurements were then converted to basal areas and converted to a 1-ha 
basis for comparison of growth increment over time.

Statistical - Statistical analysis were made using ANOVA to compare median. The Wilcoxon rank-sum test and Pearson test to compare phenological variables and Pearson correlations, respectively, was used to access biotic variation in comparison with abiotic variations.

\section{Results}

Abiotic factors - Rainfall and tide levels exhibited distinct seasonal patterns (figure 2A, B). During the year of 1989 , rainfall totaled $3,761 \mathrm{~mm}$, which, approximately, $67 \%$ were found in a first 6 months period (January to June). Monthly rainfall exhibited a major peak in the middle of the rainy season (February to May) and a smaller peak in the middle of the dry season (August to November). For the year as a whole, maximum rainfall occurred in April (544 mm) and minimum rainfall in November $(86 \mathrm{~mm})$.

Mean high tide levels likewise a bimodal pattern, with the maximum coinciding with the equinoxes: the major peak occurred in March-April, and a smaller peak during September-October. For the year of the study (figure 2B) the maximum mean high tide level occurred in March (312.7 cm above mean sea level) and the minimum in July ( $277.8 \mathrm{~cm}$ above mean sea level).

Phenology - Flowering exhibited a pattern roughly inverse to that of rainfall (figure 2C): the maximum flowering indices occurred during the dry season and the minimum indices occurred during the rainy season. For the six-month period June-November, the mean flowering index was $19.0 \pm 1.95$ (mean \pm standard error), while for the period from December and January-May the mean was $7.6 \pm 1.1$; these values were significantly different (Wilcoxon rank-sum test, $\mathrm{W}=15, \mathrm{p}=0.004$ ).

A highly significant negative correlation was found between flowering and rainfall (Pearson correlation coefficient $=-0.65, p<0.05)$. While the negative correlation between the two was extremely strong during the rainy season, when maximum flowering coincided with the minor September-October peak in tide levels (figure 2A, B, C).

During a 7-month period (January-April and October-December), the fruiting index remained constantly high $(28.3 \pm 0.87)$ and, in comparison with the remaining 5 months of the year $(10.6 \pm 1.88)$, was significantly greater $(\mathrm{W}=21, \mathrm{p}=0.001)$ (figure 2$)$. The fruiting index attained minimum values during June (7.2) and July (4.4), when mean high tide levels were also at their lowest: $273.1 \mathrm{~cm}$ and $273.3 \mathrm{~cm}$ above mean sea level, respectively. During the rest of the year, the mean fruiting index $(23.7 \pm 2.1)$ and mean high tide levels $(291.6 \pm 3.4 \mathrm{~cm}$ above mean sea level) were higher.

The 7-month fruiting peak overlapped with the monthly minima (October-November) and maximum (March) in rainfall. Furthermore, the months of minimum fruiting (May-September), preceded the months of minimum rainfall (October-November). Nevertheless, a significant, positive correlation between fruiting and rainfall was detected (Pearson correlation coefficient $=0.54, \mathrm{p}<0.05)$. A similar correlation was
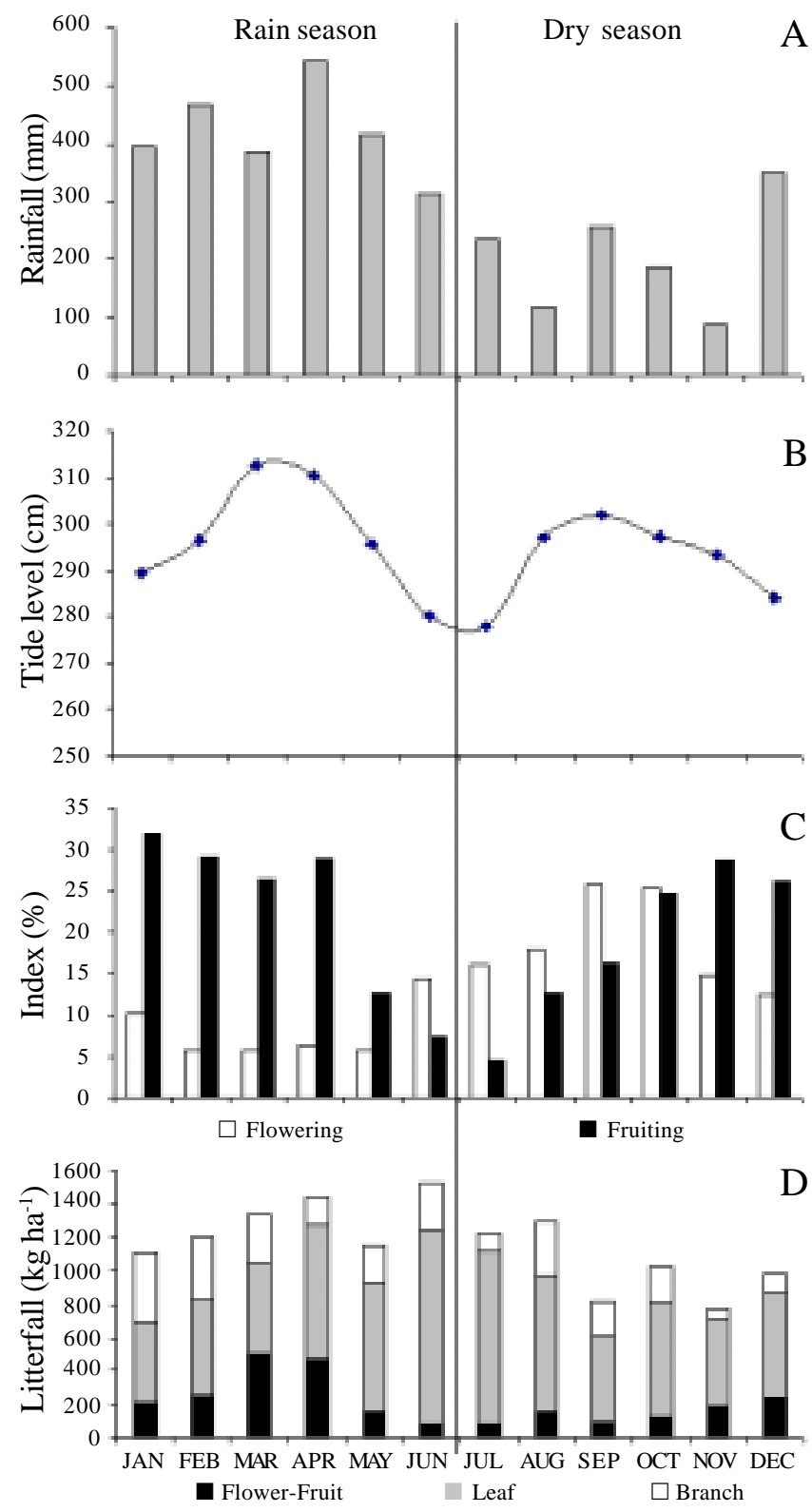

Figure 2. Rainfall and tidel level in comparison with seasonal patterns of phenology (flowering and fruiting) and litterfall (flower and fruit, leaf, and branch), in the year of 1989, in a tidal floodplain forest on Combu island, Pará, Brazil. 
found between fruiting and tide levels (Pearson correlation coefficient $=0.61, \mathrm{p}<0.05$ ).

Litterfall - Flower and fruit fall reached a distinct peak in March-April, when mean high tides were also at peak values and rainfall was relatively high (figure 2D). Monthly flower and fruit fall was significantly greater during March-April $\left(470 \pm 199 \mathrm{~kg} \mathrm{ha}^{-1}\right)$ than during the remaining ten months of the year $\left(154 \pm 10 \mathrm{~kg} \mathrm{ha}^{-1}\right)$ $(\mathrm{t}=4.18, \mathrm{p}<0.01)$. This pattern was roughly similar those exhibited by rainfall and tide levels. As a result, highly significant correlations were observed between flower and fruit fall and rainfall (Pearson correlation coefficient $=0.77, p<0.01$ ), and tide levels (Pearson correlation coefficient $=0.89, \mathrm{p}<0.01$ ).

Leaf fall showed a moderate peak during AprilAugust, which corresponded to a period of generally declining rainfall and tide levels (figure 2A, C, D). In comparison with the remaining months of the year $\left(566 \pm 23 \mathrm{~kg} \mathrm{ha}^{-1}\right)$, monthly leaf fall during April-August $\left(905 \pm 46 \mathrm{~kg} \mathrm{ha}^{-1}\right)$ was significantly higher $(\mathrm{t}=6.31$, $\mathrm{p}<0.01$ ). During the period of maximum leaf fall (AprilAugust), rainfall and tide levels were generally declining (figure 2A, B). As a result, no significant correlation between leaf fall and rainfall or tide levels was detected, although the latter correlation was weakly negative (Pearson correlation coefficient $=-0.44, \mathrm{p}=0.08$ ).

Branch fall refers to primarily branches, twigs, and bark caught in the litter traps. There was a slight peak in branch fall during the rainy (figure 2D), where the branch fall was significantly higher $(t=3.81, p<0.05)$. There was significantly higher branch fall during the rainy season (January-June: $295.3 \pm 25.0 \mathrm{~kg} \mathrm{ha}^{-1}$ ) than during the dry (July-December: $176.0 \pm 18.6 \mathrm{~kg} \mathrm{ha}^{-1}$ ). In this direction, branch fall exhibited a significant and positive correlation with rainfall (Pearson correlation coefficient $=0.52, \mathrm{t}<0.05$ ).

Total litterfall showed no noticeable pattern during the year. In general, it was slightly - although not significantly - higher during January-June $(1,295$ $\left.\pm 102 \mathrm{~kg} \mathrm{ha}^{-1}\right)$ than during July-December $(1,020 \pm$ $\left.56 \mathrm{~kg} \mathrm{ha}^{-1}\right)$. No correlation between total litterfall and either rainfall or tide levels was detected.

Of particular note was the high amount of total litterfall in the tidal floodplain forest. An estimated $13.8 \mathrm{Mg} \mathrm{ha}^{-1} \mathrm{yr}^{-1}$ of litter was generated in this forest, of which $18.1 \%\left(2.5 \mathrm{Mg} \mathrm{ha}^{-1} \mathrm{yr}^{-1}\right)$ consisted of flowers and fruits, $63.1 \%\left(8.7 \mathrm{Mg} \mathrm{ha}^{-1} \mathrm{yr}^{-1}\right)$ consist of leaves, and $18.8 \%\left(2.6 \mathrm{Mg} \mathrm{ha}^{-1} \mathrm{yr}^{-1}\right)$ consisted of branches. Root distribution - The sedimentation processes that formed the island should result in coarse-textured, and therefore lighter, soils on high sites (levels) and fine- textured, heavy soils in low-lying sites. Yet measurements from the root sampling pits revealed decreasing bulk density as topography decreased (table 1). Low-lying sites may have lower bulk density because of a greater frequency of inundation and sediment removal.

Contrary to our prediction, total root biomass to $1 \mathrm{~m}$ depth showed no significant differences between the topographically low $\left(40 \pm 9.3 \mathrm{Mg} \mathrm{ha}^{-1}\right)$, intermediate $\left(36 \pm 8.1 \mathrm{Mg} \mathrm{ha}^{-1}\right)$, and high sites $\left(35 \pm 4.8 \mathrm{Mg} \mathrm{ha}^{-1}\right)$ ( $p>0.05$, figure 3 ). Likewise, throughout the entire $1 \mathrm{~m}$ deep soil profile, the biomass of fine roots $(\geq 2 \mathrm{~mm}$ in diameter) showed no significant variation between topographic position (figure 3). Between $60-100 \mathrm{~cm}$ in depth, mean biomass of thick roots ( $>2 \mathrm{~mm}$ in diameter) was greater in the low sites than in the intermediate and high sites (figure 3), although the differences were not significant. The only significant differences in thick root biomass occurred at $0-10 \mathrm{~cm}$ (high sites $>$ low sites, $\mathrm{p}<0.05$ ) and at 50-60 cm (high sites > intermediate sites, $\mathrm{p}<0.05)$.

Growth - The tidal floodplain forest examined in this study exhibited a moderately high basal area ( $32.5 \mathrm{~m}^{2} \mathrm{ha}^{-1}$ for all plants with $\mathrm{dbh} \geq 5 \mathrm{~cm}$, table 2). The forest also exhibited a basal area increment of $1.3 \mathrm{~m}^{2} \mathrm{ha}^{-1} \mathrm{yr}^{-1}$, or $4 \%$ of the initial basal area. Such high increment indicates that the forest was undergoing rapid successional growth, despite a prolonged period of minimal disturbance.

In assertion, the composition of the forest is changing. Dicotyledonous trees represented $92.1 \%$ of the initial basal area and $76.4 \%$ of the annual basal area increment (table 2). Although palms (6.9\%) and liana $(1.0 \%)$ represented a small proportion of the initial basal area, their share of the annual basal increment was considerably higher: $10.0 \%$ and $7.7 \%$, respectively. These findings indicate that a substantial proportion of growth in this forest was allocated to palms and lianas.

Analyzing structure and growth according to diameter class, a similar pattern emerges (table 3 ). Large-girthed plants $(\mathrm{dbh}>20 \mathrm{~cm})$ - which consisted almost entirely of dicotyledonous trees in this forest represented $76.0 \%$ of the initial basal area and $57.7 \%$ of the annual basal area increment. On the other hand, small-girthed plants $(\mathrm{dbh} \geq 20 \mathrm{~cm})$, which included all palms and lianas, represented $24.0 \%$ of the initial basal area and $42.3 \%$ of the annual basal area increment. An analysis of stem diameter increment in each diameter class reveals significantly greater diameter increment per stem in large-girthed plants $\left(0.66 \mathrm{~cm} \mathrm{yr}^{-1}\right)$ than in small-girthed plants $\left(0.30-0.31 \mathrm{~cm} \mathrm{yr}^{-1}\right)$ (table 3$)$. 

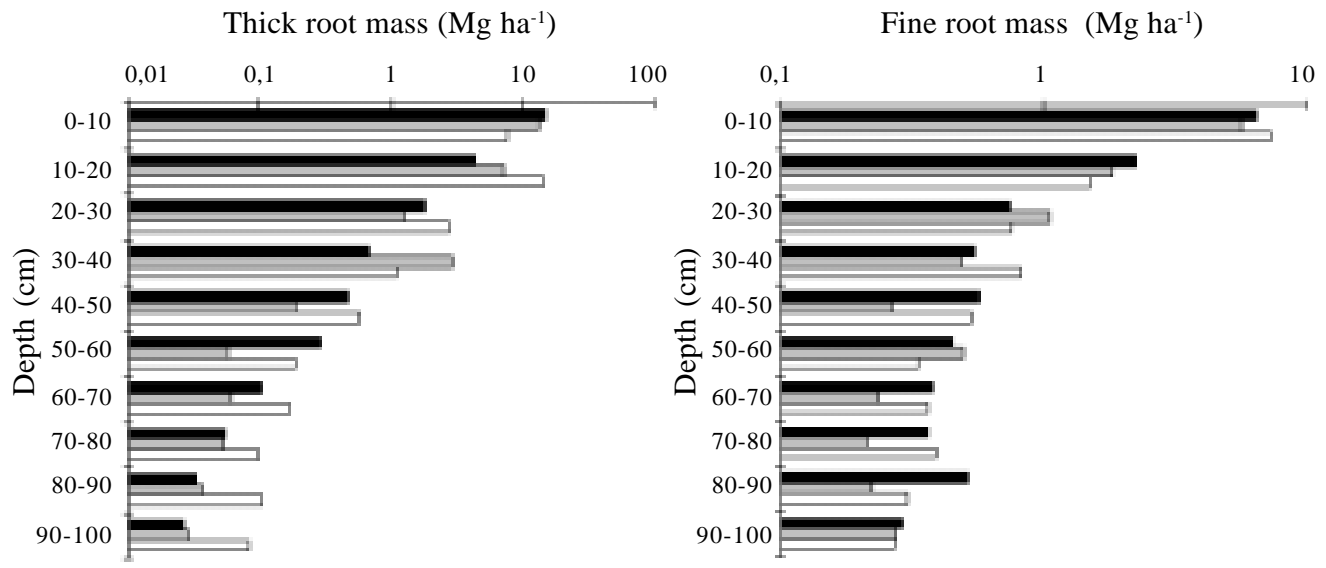

Figure 3. Distribution of thick and fine root mass on topographically high ( $\square$ ), intermediate ( $\square$ ), and low ( $\square$ ) sites on Combu island, Pará, Brazil.

Table 2. Initial basal area and basal area increment according to life form in a tidal floodplain forest, Combu island, Pará, Brazil. Dbh $\geq 5.0 \mathrm{~cm}$.

\begin{tabular}{lrrrrr}
\hline Life Form & \multicolumn{2}{c}{$\begin{array}{c}\text { Initial basal } \\
\text { area }\end{array}$} & & \multicolumn{2}{c}{$\begin{array}{c}\text { Basal area } \\
\text { increment }\end{array}$} \\
\cline { 2 - 3 } \cline { 5 - 6 } $\mathrm{m}^{2} \mathrm{ha}^{-1}$ & $\%$ & & $\mathrm{ha}^{-1} \mathrm{yr}^{-1}$ & $\%$ \\
\hline Dicotyledonous trees & 29.93 & 92.1 & & 1.07 & 76.4 \\
Palms & 2.25 & 6.9 & & 0.13 & 10.0 \\
Lianas & 0.32 & 1.0 & & 0.10 & 7.7 \\
Total & 32.50 & 100.0 & & 1.30 & 100.0 \\
\hline
\end{tabular}

\section{Discussion}

In the tidal floodplain forest on Combu Island, flowering and fruiting showed distinctive patterns of production with positive correlation with dry season and tide level, respectively. This latter correlation leads one to hypothesize that the timing of fruit maturation within the tidal floodplain forest may be broadly adapted to maximize dispersal of propagules by floods. While this observation may be valid for individual species that exhibit obvious adaptations for water-borne dispersal (e.g., Hura crepitans L., Crudia oblonga Benth., Mora paraensis Ducke, Virola surinamensis (Rol.) Warb., Pterocarpus officialis Jacq.), there is little evidence on the community level to support this hypothesis.

In fact, comparisons with other humid tropical forests those are not subject to flooding show that flowering and fruiting patterns on Combu are similar to those occurring over a wide range of ecological conditions. For example, Alencar et al. (1979) reported a dry-season flowering peak in a closed, upland ("terra firme") forest near Manaus, Brazil. In a tropical wet forest in Veracruz, Mexico, Carabias \& Guevara (1985) found a dry-seasonal peak in flowering, while fruiting peaked at the end of the dry season and the beginning of the wet season. However, in a tropical wet forest in Costa Rica, Frankie et al. (1974) found no seasonal pattern in flowering, and a slight dry-season peak in fruiting.

Table 3. Initial basal area, basal area increment, and per-stem diameter increments by dbh size class in a tidal floodplain forest, Combu island. (Standard errors in parentheses). Tuckey test $b>a, p<0.01$

\begin{tabular}{|c|c|c|c|c|c|}
\hline \multirow[t]{2}{*}{ Dbh Class (cm) } & \multicolumn{2}{|c|}{ Initial basal area } & \multicolumn{2}{|c|}{ Basal area increment } & \multirow{2}{*}{$\begin{array}{c}\text { Per stem diamenter } \\
\text { increment }\end{array}$} \\
\hline & $\mathrm{m}^{2} \mathrm{ha}^{-1}$ & $\%$ & $\mathrm{~m}^{2} \mathrm{ha}^{-1} \mathrm{yr}^{-1}$ & $\%$ & \\
\hline $5-10$ & 2.67 & 8.2 & 0.28 & 21.5 & $0.31(0.03)^{\mathrm{a}}$ \\
\hline $10-20$ & 5.12 & 15.8 & 0.27 & 20.8 & $0.30(0.05)^{\mathrm{a}}$ \\
\hline $20-40$ & 7.87 & 24.2 & 0.26 & 20.0 & $0.45(0.09)^{\mathrm{ab}}$ \\
\hline$>40$ & 16.84 & 51.8 & 0.49 & 37.7 & $0.66(0.20)^{\mathrm{b}}$ \\
\hline Total & 32.50 & 100.0 & 1.30 & 100.0 & \\
\hline
\end{tabular}


These comparative studies suggest that the timing of flowering and fruiting, exhibited by the tidal floodplain forest, take place in a wide geographic range. This similarity lead us to suspect that, at least on the community level, the observed correlations between phonological events and tide levels on Combu probably do not reflect a direct causal relationship, but rather the interactions between tide levels and rainfall.

Root biomass of the floodplain forest on Combu island (35.6 $\left.\mathrm{Mg} \mathrm{ha}^{-1}\right)$ was low to intermediate compared to other mature Neotropical forests (table 4). In contrast to other mature neotropical forests (cf. many references in table 4, which used the same sampling method), on Combu the decrease in thick and (especially) fine root biomass below $50 \mathrm{~cm}$ depth was relatively slight, and root biomass at $100 \mathrm{~cm}$ depth was relatively high. These observations suggest that root biomass occurred below the $1 \mathrm{~m}$ sampling depth at all topographic levels. On the other hand, the total root biomass of the floodplain forest on Combu island was generally higher than upland, secondary forests of 20-80 yr in Venezuela and Costa Rica (table 4).

The presence of relatively high root biomass deep in the soil profile is especially noteworthy in an ecosystem subject to periodic flooding and characterized by heavy clay soils that are presumably poor in oxygen. Observations in the soil pits established as part of this study revealed a high concentration of roots around buried deposits of organic material, which presumably decomposes slowly under anaerobic soil conditions. Such deposits could provide the vegetation with a supplemental source of nutrients. In addition, deeply penetrating roots could play an important role in stabilizing the vegetation and, ultimately, reducing erosion.

In contrast to our prediction, this study did not detect a higher concentration of root biomass near the soil surface in topographically low sites. However, we found greater (although not statistically significant) biomass of thick roots at $60-100 \mathrm{~cm}$ depth on topographically

Table 4. Comparison of total root biomass of neotropical forests.

\begin{tabular}{|c|c|c|c|c|c|}
\hline Reference & Local & Forest type & Soil type & $\begin{array}{c}\text { Depth of } \\
\text { sampling }(m)\end{array}$ & $\begin{array}{r}\text { Biomass } \\
\left(\mathrm{Mg} \mathrm{ha}^{-1}\right)\end{array}$ \\
\hline Klinge (1973) & $\begin{array}{l}\text { Manaus } \\
\text { Brazil }\end{array}$ & $\begin{array}{l}\text { primary forest } \\
\text { (upland) }\end{array}$ & Spodosol & 0.5 & 40.0 \\
\hline Klinge \& Herrera (1978) & $\begin{array}{l}\text { São Carlos } \\
\text { Venezuela }\end{array}$ & $\begin{array}{l}\text { primary forest } \\
\text { (upland) }\end{array}$ & Spodosol & 1.0 & 132.0 \\
\hline Sanford (1989) & $\begin{array}{l}\text { São Carlos } \\
\text { Venezuela }\end{array}$ & $\begin{array}{l}\text { primary forest } \\
\text { (upland) }\end{array}$ & Spodosol & 0.5 & 60.6 \\
\hline Stark \& Spratt (1977) & $\begin{array}{l}\text { São Carlos } \\
\text { Venezuela }\end{array}$ & $\begin{array}{l}\text { primary forest } \\
\text { (upland) }\end{array}$ & Oxisol & 0.5 & 55.6 \\
\hline Nepstad (1989) & $\begin{array}{l}\text { Paragomins } \\
\text { Brazil }\end{array}$ & $\begin{array}{l}\text { primary forest } \\
\text { (upland) }\end{array}$ & Oxisol & 1.0 & 27.9 \\
\hline Sanford (1989) & $\begin{array}{l}\text { São Carlos, } \\
\text { Venezuela }\end{array}$ & $\begin{array}{l}\text { primary forest } \\
\text { (upland) }\end{array}$ & Oxisol & 0.5 & 60.9 \\
\hline Komiyama et al.(1987) & Thaiwa & Mangrove forest & & 1.0 & 509.5 \\
\hline Frangi \& Lugo (1985) & Porto Rico & primary forest (floodplain) & & 1.0 & 61.7 \\
\hline This study & $\begin{array}{l}\text { Belém } \\
\text { Brazil }\end{array}$ & $\begin{array}{l}\text { Secondary forest } 40 \text { years } \\
\text { old (floodplain) }\end{array}$ & Inceptisol & 1.0 & 36.2 \\
\hline Saldarriaga et al. (1988) & $\begin{array}{l}\text { SCRN } \\
\text { Venezuela }\end{array}$ & $\begin{array}{l}\text { Secondary forest, } 20 \text { years } \\
\text { old (upland) }\end{array}$ & Oxisol & 0.7 & 15.2 \\
\hline Saldarriaga et al. (1988) & $\begin{array}{l}\text { SCRN } \\
\text { Venezuela }\end{array}$ & $\begin{array}{l}\text { Secondary forest } 30 \text { years } \\
\text { old (upland) }\end{array}$ & Oxisol & 0.7 & 16,7 \\
\hline Saldarriaga et al. (1988) & $\begin{array}{l}\text { SCRN } \\
\text { Venezuela }\end{array}$ & $\begin{array}{l}\text { Secondary forest } 60 \text { years } \\
\text { old (upland) }\end{array}$ & Oxisol & 0.7 & 42.0 \\
\hline Berish (1982) & $\begin{array}{l}\text { Turrialba } \\
\text { Costa Rica }\end{array}$ & $\begin{array}{l}\text { Secondary forest } 70 \text { years } \\
\text { old (upland) }\end{array}$ & & 0.85 & 15.6 \\
\hline Saldarriaga et al. (1988) & $\begin{array}{l}\text { SCRN } \\
\text { Venezuela }\end{array}$ & $\begin{array}{l}\text { Secondary forest } 80 \text { years } \\
\text { old (upland) }\end{array}$ & Oxisol & 0.7 & 17.2 \\
\hline
\end{tabular}


low sites than on high sites (figure 3), possibly due to i) lower soil density on the low sites (table 1) or ii) the ability of Euterpe oleracea, a characteristic species of low sites, to root deeply in the soil (Cattanio et al. 2002). We observed that the distinctive orange roots of E. oleracea comprised $>50 \%$ of the root mass below $50 \mathrm{~cm}$ depth in the low sites. The aerenchyma observed in these roots, and the zones of soil oxidation associated with them, suggest that E. oleracea is well adapted to rooting in flooded soils.

In comparison to flowering and fruiting, litterfall in the tidal floodplain forest showed generally weaker correlations to both rainfall and tide levels. The significant correlations to flower and fruit fall simply reflect similarly correlations to flowering and fruiting. Although it occurred throughout the year, leaf fall showed a distinct peak in June, when both rainfall accumulation at time and potential losses due to leaching or tide-driven floods would be minimal.

Yet comparisons with other ecosystems provide little support for this hypothesis. In a variety of noninundated humid tropical forests in the Central Amazon of Brazil (Alencar et al. 1979), and the Atlantic lowlands of Costa Rica (Frankie et al. 1974), researchers have observed distinct pulses in leaf fall at the outset of the dry season were observed. Most significantly, Adis et al.
(1979) found a similar early dry-season pulse in a blackwater swamp ("igapó") forest, at precisely the time when floodwaters were also at their peak. Rather than a strategy for future sequestering of nutrients, the timing of leaf fall appears to be a response to more proximal factors such as increasing plant water stress. In Central Amazon floodplain forest the most tree species show increased leaf fall, but also leaf flush, flowering and fruiting during the highwater period (Adis et al. 1979, Wittmann \& Parolin 1999). Adis et al. (1979) studding "igapós" with black water, showed that the concentration of different mineral elements in the leaf debris are smaller during of flooding period (before the raise of the level of water) in compared with the period after immersion (low water level). That adaptation factor from "igapó" plants to nutrient retention brought for the suspension sediments in river's water seems to happen in the "várzea" forest of the Combu Island.

Although the temporal pattern of litterfall is not distinctive, the amount of litterfall generated in this ecosystem is extraordinary. The $13.8 \mathrm{Mg} \mathrm{ha}^{-1} \mathrm{yr}^{-1}$ of litterfall measured in this study is considerably higher than figures reported from other upland and inundated forest in the Brazil Amazon, which range from 6.4-10.7 $\mathrm{Mg} \mathrm{ha}^{-1} \mathrm{yr}^{-1}$ (table 5). Even among Amazonian floodplain forests, the litterfall measured in this study is

Table 5. Composition of litterfall in upland, floodplain and swamp forests in the Brazilian Amazon. With* symbol includes unrecognizable plant debris and frass

\begin{tabular}{|c|c|c|c|c|c|c|}
\hline \multirow[b]{2}{*}{ Source } & \multirow[b]{2}{*}{ State } & \multirow[b]{2}{*}{ Forest type } & \multicolumn{4}{|c|}{ Litterfall $\left(\mathrm{Mg} \mathrm{ha}^{-1} \mathrm{yr}^{-1}\right)$} \\
\hline & & & Flowers \& Fruits & Leaves & Branches & Total \\
\hline Klinge \& Rodrigues (1968) & Amazonas & Upland & 0.4 & 5.6 & 1.1 & 7.3 \\
\hline Klinge et al.(1975) & Amazonas & Upland & 0.2 & 4.0 & 3.0 & 7.2 \\
\hline Flanken et al. (1979) & Amazonas & Upland & 0.5 & 6.5 & 1.0 & 8.0 \\
\hline Silva (1984) & Amazonas & Upland & 0.5 & 4.7 & 1.4 & 6.6 \\
\hline Luizão(1989) & Amazonas & Upland & 0.4 & 5.4 & 1.6 & 8.3 \\
\hline Luizão(1989) & Amazonas & Upland & 0.4 & 4.7 & 1.2 & 7.4 \\
\hline Scott et al. (1992a) & Roraima & Upland & 1.2 & $* 6.7$ & 1.3 & 9.3 \\
\hline Scott et al. (1992b) & Roraima & Upland & 0.6 & 5.4 & 0.8 & 6.9 \\
\hline Silva \& Lobo (1982) & Pará & Upland & 0.3 & 6.1 & 0.9 & 7.3 \\
\hline Klinge (1978) & Pará & Upland & 0.8 & 8.1 & 1.3 & 10.2 \\
\hline Franken et al. (1979) & Amazonas & Floodplain & 1.0 & 4.3 & 1.1 & 6.4 \\
\hline Silva \& Lobo (1982) & Pará & Floodplain & 1.0 & 6.5 & 1.1 & 8.6 \\
\hline Klinge (1978) & Pará & Floodplain & 0.6 & 8.7 & 1.4 & 10.7 \\
\hline This study & Pará & Floodplain & 2.5 & 8.7 & 2.6 & 13.8 \\
\hline Adis et al. (1979) & Amazonas & Swamp & 0.5 & 5.3 & 1.0 & 6.8 \\
\hline Franken et al. (1979) & Amazonas & Swamp & 0.5 & 5.2 & 1.0 & 6.7 \\
\hline Silva \& Lobo (1982) & Pará & Swamp & 0.4 & 6.2 & 1.1 & 7.7 \\
\hline Klinge (1978) & Pará & Swamp & 0.4 & 7.4 & 0.7 & 8.6 \\
\hline
\end{tabular}


exceptionally high. In addition, the forest on Combu exhibited a high rate of stem increment (table 5).

This high litterfall and growth appear to reflect, in part, the successional status of the tidal floodplain forest on Combu island. Despite a prolonged period (ca. $30 \mathrm{yr}$ ) with little disturbance, this forest is undergoing rapid change. An analysis of different life forms and size classes (tables 2,3) indicates that the high growth of this forest is channeled primarily to a few dominant trees in the canopy (as well as accompanying lianas), and to numerous individuals (including palms, lianas, and small dicotyledonous trees) in the understory. Over time, we suspect that as the canopy closes, growth in the understory will decline markedly.

The high productivity of floodplain forests in general can be discerned by comparing litterfall with other Amazonian forest types (table 5). In general , mean litterfall is $9.9 \pm 1.6 \mathrm{Mg} \mathrm{ha}^{-1} \mathrm{yr}^{-1}$ in floodplain forests, $7.5 \pm 0.4 \mathrm{Mg} \mathrm{ha}^{-1} \mathrm{yr}^{-1}$ in blackwater swamp forest, and $7.8 \pm 0.4 \mathrm{Mg} \mathrm{ha}^{-1} \mathrm{yr}^{-1}$ in upland forest. Although these differences are not significant, they indicate that litterfall in floodplain forests is relatively high compared with other Amazonian forest types. These findings show that large-girthed trees grew rapidly, but as a group, their low numbers resulted in relatively little overall growth. On the other hand, smallgirthed plants (especially palms and lianas) grew slowly, but as a group, their high numbers resulted in substantial overall growth.

These study suggest that floodplain forest is, all together, highly productive ecosystems. In addition to litterfall, this productivity is likely to be manifest in relatively high rates of forest recovery following disturbance (cf. Frangi \& Lugo 1985, Salo et al. 1986). Such resiliency has probably contributed to sustaining forest-based activities in the floodplain of the Amazon and its tributaries for over three centuries.

Acknowledgements - This study is part of an interdisciplinary research and extension program administered by the Emílio Goeldi Museum of Pará and supported by the Ford Foundation and the British Overseas Development Administration (ODA). We express our gratitude to the Superintendência do Desenvolvimento da Amazônia (Sudam) and the Companhia Docas do Pará, which furnished data on rainfall and tide levels, respectively. We also thank Mr. Eugênio Cichovsky, on whose land the study took place; Mr. Sérgio Henrique Tonin for assisting in the field work; Ms. Jacirema R. da Costa for assisting in the laboratory; and Mr. Antônio Dourado for help in the data analysis. Finally, we express special gratitude to the inhabitants of Combu island who collaborated in this study.

\section{References}

ADIS, J., FURGH, K. \& IRMLER, U. 1979. Litter production of a Central-Amazonian black water inundation forest. Tropical Ecology 20:236-245.

ALENCAR, J.C., ALMEIDA, R.A. \& FERNANDEZ, N.P. 1979. Fenologia de espécies florestais em floresta tropical úmida de terra firme na Amazônia Central. Acta Amazonica 9:163-198.

ANDERSON, A.B. 1990. Extraction and forest management by rural inhabitants in the Amazon estuary. In Alternatives to deforestation: steps toward sustainable use of the Amazon rain forest (A.B. Anderson, ed.). Columbia University Press, New York, p.65-85.

BAYLEY, P.B. \& PETRERE, M. 1989. Amazon Fisheries: Assessment methods, current status and management options. Canadian Special Publication Fisheries Aquatic Sciences 106:385-398.

BERISH, C.W. 1982. Root biomass and surface area in tree successional tropical forests. Canadian Journal of Forest Research 12:699-704.

CARABIAS, L.J. \& GUEVARA, S. 1985. Fenologia en una selva tropical húmeda y en una comunidade derivada; Los Tuxtlas, Veracruz. Investigaciones sobre la Regeneración de Selvas Altas en Veracruz, México, (A. Gómez-Pompa \& E. Del Amo R., eds.). Editorial Alhambra Mexicana, Mexico v.3 p.27-66.

CATTANIO, J.H., ANDERSON, A.B. \& CARVALHO, M.S. 2002. Floristic composition and topographic variation in a tidal floodplain forest in the Amazon Estuary. Revista Brasileira de Botânica 25:419-430.

FALESI, I.C. 1974. Soils of the Brazilian Amazon. In Man in the Amazon (C. Wagley, ed.). University of Florida Press, Gainesville, p.201-229.

FRANGI, J.L. \& LUGO, A.E. 1985. Ecosystem dynamics of a subtropical floodplain forest. Ecological Monographs 55:351-369.

FRANKEN, M., IRMLER, U. \& KLINGE, H. 1979. Litterfall in inundation, riverine and terra firme forests of central Amazônia. Tropical Ecology 20:225-235.

FRANKIE, G.W., BAKER, H.G. \& OPLER, P.A. 1974. Comparative phenological studies of trees in tropical wet and dry forests in the lowlands of Costa Rica. Journal of Ecology 62:881-913.

GENTRY, A.H. \& DODSON, C. 1987. Contribution of notrees to species richness of a tropical rainforest. Biotropica 19:149-156.

GIBBS, R.J. 1967. Amazon River: environmental factors that control its dissolved and suspended load. Science 156:1734-1736.

IRION, G. 1983. Sedimentalogical studies of the "ilha de Marchantaria" in the Solimões/Amazon river, near Manaus. Amazoniana 7:1-18.

KAHN, F. \& MEJIA, K. 1990. Palm communities in wetland forest ecosystems of Peruvian Amazonian. Forest Ecology \& Management 33/34:169-179. 
KLINGE, H. 1973. Root mass estimation in lowland tropical rain forests of central Amazonia, Brazil. I. Fine root masses of a pale yellow latossol and a giant humus podzol. Tropical Ecology 14:29-38

KLINGE, H. 1978. Litter production in tropical ecosystems. Malay Natural Journal 30:415-422.

KLINGE, H. \& HERRERA, R. 1978. Biomass studies in Amazon caatinga forest in southern Venezuela. I. Standing crop of composite root mass in selected stands. Tropical Ecology 19:93-110.

KLINGE, H. \& RODRIGUES, W.A. 1968. Litter production in an area of Amazonian terra firme forest. Part I. Litterfall organic carbon and total nitrogen contents of litter. Amazoniana 1:287-302.

KLINGE, H., RODRIGUES, W.A., BRUNING, E. \& FITTKAU, E.J. 1975. Biomass and structure in a central Amazonian rain forest. In Tropical Ecological Systems (F.B. Golley \& E. Medina, eds.) Springer, New York, p.115-122.

KOMIYAMA, A., OGINO, K., AKSONKOAE, S. \& SABHASRI, S. 1987. Root biomass of a mangrove forest in southern Thailand. 1. Estimation by the trench method and the zonal structure of root biomass. Journal of Tropical Ecology 3:97-108.

LIMA, R.R. 1956. A agricultura nas várzeas do estuário amazônico. Boletim Técnico do Instituto Agronômico do Norte 33:1-164.

LUIZÃO, F.J. 1989. Litter production and mineral element input to the forest floor in a central Amazonian forest. Geo Journal 19:407-417.

MEGGERS, B.J. 1971. Amazonia: man and culture in a counterfeit paradise. Aldine Publ. Co., Chicago.

NEPSTAD, D. 1989. Forest regrowth in abandoned pasture of eastern Amazonia. Ph D. Dissertation, Yale University, New Haven.

PADOCH, C., CHOTA-INUMA, J., DE JONG, W. \& UNRUH, J. 1985. Amazonian agroforestry: A market-oriented system in Peru. Agroforestry Systems 3:47-58.

PIRES, J.M. \& KOURY, H.M. 1958. Estudo de um trecho de mata de várzea próximo a Belém. Boletim Técnico do Instituto Agronômico do Norte 36:3-44.

ROOSEVELT, A.C. 1980. Parmana: prehistorie maize and manioc subsistence along the Amazon and Orinoco. Studies in Archeology, Academic Press, New York.

SALDARRIAGA, J.G., WEST, D.C., THARP, M.L. \& UHL, C. 1988. Long-term chronosequence of forest succession in the upper Rio Negro of Columbia and Venezuela. Journal of Ecology 76:938-958.
SALO, J., HAKKINEN, I., MAKINEN, Y., NIEMELA, P., PUHAKKA, M. \& COLEY, P.D. 1986. River dynamics and the diversity of Amazon lowland forest. Nature 322:254-258.

SANFORD JUNIOR, R.L. 1989. Root systems of three adjacent, old growth Amazon forests and associated transition zones. Journal of Tropical Forest Science 1:268-279.

SCHUURMAN, J.J. \& GOEDEWAAGEN, M.A.J. 1965. Methods for the examination of root systems and roots. Center for Agricultural Publications and Documentation, Wageningen.

SCOTT, D.A., PROCTOR, J. \& THOMPSON, J. 1992a. Ecological studies on a lowland evergreen rainforest on Maracá Island, Roraima, Brazil, II. Litter and nutrient cycling. Journal of Ecology 80:705-717.

SCOTT, D.A., PROCTOR, J. \& THOMPSON, J. 1992b. A semievergreen forest on Maracá Island, II. Litter and nutrient cycling. The Rainforest Edge. Plant and Soil Ecology of Maracá Island, Brazil (J. Hemming, ed.). Manchester University Press, Manchester, p.30-44.

SILVA, M.F.F. 1984. Produção de serrapilheira e seu conteúdo minerológico em mata de terra firme, Tucurui (PA). Boletim do Museu Emilio Goeldi (Série Botânica) $1: 111-158$.

SILVA, M.F.F. \& LOBO, M.G.A. 1982. Nota sobre decomposiçäo de materia orgânica em floresta de terra firme, várzea e igapó. Boletim do Museu Paraense Emilio Goeldi (Série Botância) 1:111-158.

SIOLI, H. 1951. Sobre a sedimentação na várzea do baixo Amazonas. Boletim Técnico do Instituto Agronômico do Norte 24:47-67.

SIOLI, H. \& KLINGE, H. 1962. Solos, tipos de vegetação e águas na Amazônia. Boletim do Museu Paraense Emilio Goeldi 1:27-47.

STARK, N. \& SPRATT, M. 1977. Root biomass and nutrient storage in rain forest oxisols near San Carlos de Rio Negro. Tropical Ecology 18:1-9.

SUDAM. 1984. Atlas Climatológico da Amazônia Brasileira, Superintendência do Desenvolvimento da Amazônia, Belém.

VIEIRA, L.S. 1979. Reconhecimento dos recursos minerais da região metropolitana de Belém. Unpublished report, SPLAN/Codem/Idesp, Belém.

WITTMANN, F. \& PAROLIN, P. 1999. Phenology of six tree species from central Amazonian várzea. Ecotropica 5:51-57. 